\title{
A RECCS 2016 TAPASZTALATAI
}

\section{THE EXPERIENCE OF THE RECCS 2016}

\author{
Gobesz Ferdinánd-Zsongor \\ Kolozsvári Müszaki Egyetem, Épitömérnöki Kar, Tartószerkezetmechanikai Tanszék, \\ Cím: 400020 Románia, Kolozsvár, C. Daicoviciu (Bástya) u. 15; Telefon: +40-246- \\ 401351,go@mecon.utcluj.ro
}

\begin{abstract}
The third year students of the Civil Engineering Faculty from Cluj-Napoca participated with two teams at the „RECCS 2016 - World Championship in Spaghetti Bridge Building” organized by the Óbuda University, winning the first and the third place in the Bridge category. Comparing the measurements of the break tests with our structural analysis, it turned out that, during the design of such rigid and fragile structures, paying attention to get smaller deformations is more important than checking internal forces.
\end{abstract}

Keywords: spaghetti bridge, competition, engineering education.

\section{Összefoglalás}

A kolozsvári Építőmérnöki Kar harmadéves hallgatói két csapattal vettek részt az Óbudai Egyetem által szervezett „RECCS 2016 - tésztahídépítő világbajnokság”-on, első és harmadik helyet szerezve a híd kategóriában. A töréspróbák méréseit és a számításainkat összevetve kiderült, hogy e merev és törékeny alkotások tervezésénél fontosabb a minél kisebb alak változásra, mint az erők játékára figyelni.

Kulcsszavak: tésztahíd, verseny, mérnöki oktatás.

\section{Bevezetés}

A RECCS egy igen rangos és népszerü magyarországi tésztahídépítő verseny, melyet 2005-ben hirdettek meg elöször „RECCS 2005 - Kárpát Medencei Tésztahíd Építö Verseny"-ként, majd 2010-ben „Közép Európai Tésztahíd Épitő Verseny” lett [1]. A kezdetei az Ybl Miklós Müszaki Főiskolai Kar vetélkedőjéhez kötődnek, melybe 2004-ben a Bánki Dónát Gépész és Biztonságtechnikai Mérnöki Kar (akkor még Bánki Dónát Müszaki Főiskola) hallgatói is bekapcsolódtak. Eredményeiken felbuzdulva, nagy lelkesedéssel indították 2005-ben a RECCS-et, melyen eleinte négy ország hallgatói vettek részt (Magyarország, Románia, Szlovákia és Szerbia), majd 2010-ben Olaszországból és Iránból is érkeztek résztvevők. A RECCS 2011-ben az Óbudai Egyetem által szervezett „Tésztahíd Épitő Világbajnokság"-gá nőtte ki magát, melyen már 9 ország (Irán, Lettország, Magyarország, Németország, Olaszország, Portugália, Románia, Szerbia és Szlovákia) több egyetemének és föiskolájának a csapatai vettek részt [1]. Immár 2 kategóriában (híd meg tartó) folyt a verseny a teherbírás tekintetében, de innovációs meg esztétikai díjakat is osztottak. A Kolozsvári Müszaki Egyetem építőmérnök hallgatói is ez alkalommal vettek részt először a RECCS-en, 
azóta rendszeresen jelen voltak, és a sorozatosan évente megrendezett világbajnokságokon gyüjtött tapasztalatok bizonyítékaként egyre jobb eredményeket értek el.

A tésztahídépítésnek kevésbé ismert, de szép és gazdag hagyománya van világszerte, Kanadától Ausztráliáig [2]. Nem tudni pontosan, hogy mikor és hol kezdtek el ilyen szerkezeteket építeni (egyes feltételezések szerint az 1960-as évek végén Angliában), de az első komoly verseny a kanadai Okanogan College nevéhez füzödik. 1983ban hirdették meg az első ilyen nyitott mérnökhallgatói vetélkedöt, majd 1988-ban vezették be a nehézsúlyú osztályt, megkülönböztetve a tésztaszerkezeteket méreteik (és teherbíró képességük) alapján.

A RECCS is e nehézsúlyú osztály jellemzöi alapján alakította ki a versenyszabályzatát (röviden: $1000 \mathrm{~mm}$-es távolság a feltámasztási pontok között, $600 \mathrm{~mm}$-ig engedett magasság és $130 \mathrm{~mm}$-ig engedett szélesség, illetve $1000 \mathrm{~g}$ maximális ösztömeg), különbséget téve a futófelülettel rendelkező hidak meg a futófelület nélküli tartók között [1]. A töréspróbák során a száraztésztából és ragasztóból készített szerkezeteket középen lefelé húzó növekvő erőnek vetik alá, folyamatosan mérve a terhelést és a függőleges elmozdulást. A végső teherbírást az összeroppanás elötti pillanatban rögzített erő értéke adja, ennek alapján jutnak helyezéshez a versenyző csapatok.

A Kolozsvári Müszaki Egyetem csapatai az Építőmérnöki Kar hallgatói közül verbuválódnak. A világbajnokságon való részvételhez át kell esniük legalább egy helyi versenyen. A 2016 tavaszán rendezett kari vetélkedőkre eleinte 7 csapat iratkozott fel, de a végén csupán 2 csapat bizonyított (a harmadéves hallgatókból álló „Kamikaze” és „Musztáng”), mindkettő túlszárnyalva a $410 \mathrm{~kg}$-erö (402 daN) küszöbét a végső teherbírás tekintetében.

A tésztahídépítés folyamata mérnöki feladatként van kezelve. A kezdeti elképzelés után (aminek a verseny szabályzatából eredő méretek és tömegkorlát meg a különféle tésztafajták mechanikai jellemzői adják az alapját) szerkezeti modellezés és számítás következik. Amikor megfelelönek tartja a modell jellemzőit és viselkedését a csapat, akkor sablonok és segédeszközök tervezése következik. Ezt követi a szükséges anyagok beszerzése, selejtezése, majd kezdődhet az építés.

Eddigi tapasztalataink szerint a pontos és gondos kivitelezés fontosabbnak bizonyult a modellezésnél meg a szerkezeti számításnál. Előző években folytatott sorozatos kísérletek után a húzott elemekhez spagettit, a nyomottakhoz pedig rövidre vágott és csiszolt pennéket használnak, ezek átlagos teherbírási jellemzői az alábbi táblázatokban vannak röviden feltüntetve.

1. táblázat. Szakitásra mért értékek átlagai a spagettiszálak esetében [3]

\begin{tabular}{|c|c|c|}
\hline Spagettiszál & $\begin{array}{c}\text { Hossz } \\
{[\mathrm{mm}]}\end{array}$ & $\begin{array}{c}\text { Erö } \\
{[N]}\end{array}$ \\
\hline 1 & 150 & $40-60$ \\
\hline 1 & 470 & 50 \\
\hline 2 & 460 & 90 \\
\hline 4 & 480 & 150 \\
\hline 6 & 485 & 230 \\
\hline 9 & 450 & 390 \\
\hline 12 & 460 & 500 \\
\hline
\end{tabular}

2. táblázat. Nyomásra mért értékek átlagai a toldott pennedarabok esetében [3]

\begin{tabular}{|c|c|c|}
\hline Pennetoldás & $\begin{array}{c}\text { Hossz } \\
{[\mathrm{mm}]}\end{array}$ & $\begin{array}{c}\text { Erö } \\
{[N]}\end{array}$ \\
\hline 2 & 50 & -1600 \\
\hline 4 & 95 & -1200 \\
\hline 6 & 125 & -900 \\
\hline 6 & 165 & -600 \\
\hline
\end{tabular}

A tésztahidak egyik fontos része a terhelöelem, mely egy $100 \times 50 \times 10 \mathrm{~mm}$-es falemezből áll (1. ábra), melynek a közepén 9 $\mathrm{mm}$-es furatban $8 \mathrm{~mm}$-es szemes csavar van, 
alátéttel és csavaranyával rögzítve. A megfelelő fafajta kiválasztásához szintén sok kísérlet vezetett. Szemléltetésként csupán háromféle falap jellemzőit összegeztük a 3. táblázatba. Nyilvánvaló, hogy a három közül az akác a legerősebb (és a legrugalmasabb), de nem szabad figyelmen kívül hagyni a rostok irányát a falapokban.

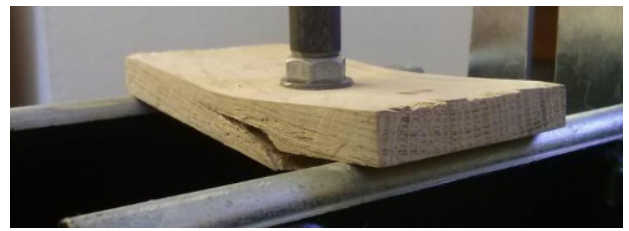

1. ábra. Egy terhelöelem töréspróbája [4].

3. táblázat. Hajlitási eredmények a fa terhelöelemek töréspróbáiból [4]

\begin{tabular}{|c|c|c|}
\hline Fafajta & $\begin{array}{c}\text { Lehajlás } \\
{[\mathrm{mm}]}\end{array}$ & $\begin{array}{c}\text { Erö } \\
{[N]}\end{array}$ \\
\hline Lucfenyö & 6,90 & 1684 \\
\hline Bükk & 7,45 & 2985 \\
\hline Akác & 13,00 & 5678 \\
\hline
\end{tabular}

\section{Előzetes számítások, tervezés és tesztelés}

A szabályszerüen elkészített szerkezetek számítási modelljeinek statikai vizsgálata diszkrét központi húzóerőkre történt, különkülön: 450, 500, 550, majd 600 kg-eröre (mivel a híd kategóriában 570,3 kg-erö, a teró kategóriában pedig 578,2 $\mathrm{kg}$-erö jelent világcsúcsot eddig [1]). A helyi selejtezőkre tervezett tésztahidak elméleti vizsgálatát a 2. és 3. ábra meg a 4. táblázat szemlélteti.

Mivel a ragasztott csomópontok és a terhelőelem (falap) anyagának a modellezése végtelen-merevként történt, nem volt eltérés a lineáris rugalmas meg a geometriailag nem lineáris (nagy elmozdulásokat figyelembe vevő) szerkezeti vizsgálat eredményei között.

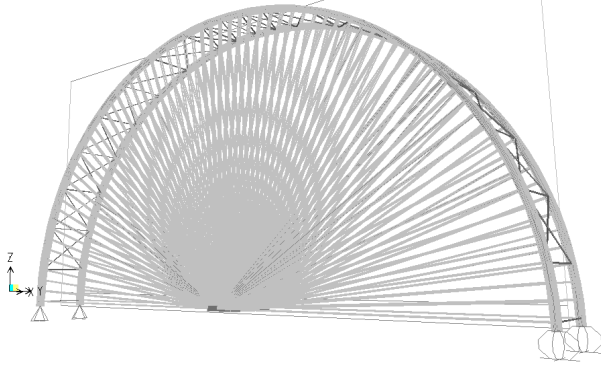

2. ábra. A helyi versenyre tervezett szerkezetek számitógépes modellje térbeli nézetben

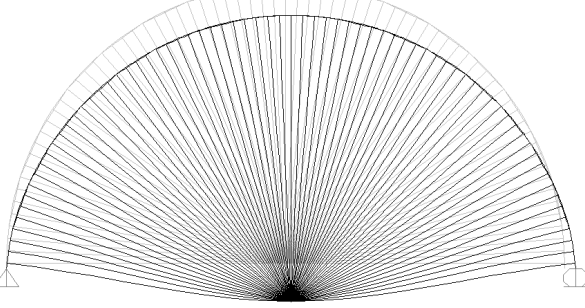

3. ábra. A tésztahíd szerkezeti modelljének az alakváltozása központi húzásra

4. táblázat. A két azonos tésztahíd számitási eredményei, soronként az emlitett húzóerőkre. A kihasználtság \%-ban értendö.

\begin{tabular}{|c|c|c|c|c|}
\hline \multirow{2}{*}{$\begin{array}{c}\text { Bekötök } \\
{[d a N]}\end{array}$} & \multirow{2}{*}{$\begin{array}{l}\text { Ívek } \\
{[k N]}\end{array}$} & \multirow{2}{*}{$\begin{array}{c}\text { Süllyedés } \\
{[\mathrm{mm}]}\end{array}$} & \multicolumn{2}{|c|}{ Kihasználtság } \\
\hline & & & Bekötők & Ívek \\
\hline \multicolumn{5}{|c|}{ Terhelés [kg-eró]: 450} \\
\hline 5,01 & $\overline{1,11}$ & 9,08 & 55,7 & 61,7 \\
\hline \multicolumn{5}{|c|}{ Terhelés [kg-erö]: 500} \\
\hline 5,56 & $\overline{1,23}$ & 10,08 & 61,8 & 68,3 \\
\hline \multicolumn{5}{|c|}{ Terhelés [kg-erö]: 550} \\
\hline 6,11 & $\overline{1,35}$ & 11,09 & 67,9 & 75,0 \\
\hline \multicolumn{5}{|c|}{ Terhelés [kg-eró]: 600} \\
\hline 6,67 & $1, \overline{4}$ & 12,10 & 74,1 & 81,7 \\
\hline
\end{tabular}

A páros spagettikböl készült bekötők szakítóértékeként az 1. táblázat 3. sorában található $90 \mathrm{~N}$ értéket, a párosan illesztett pennékből készített íveknél (4. ábra) pedig a 2. táblázat 3 . sorában látható $900 \mathrm{~N}$ nyo- 
más kétszeresét vettük számításba a kihasználtsághányad megállapításánál.

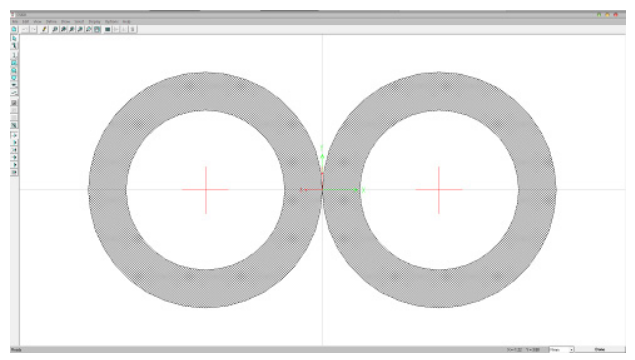

4. ábra. A párosan illesztett pennékböl tervezett ivek metszeti modellezése

A 4. táblázatban látható adatokból úgy tünik, hogy a számított modell még nagyobb terhelést is bírna, hiszen $600 \mathrm{~kg}$-erö esetén a szerkezet alkotóelemei 75-80\%ban érnék el a végső teherbírásukat. Az alakváltozások mérete viszont intő jel, hiszen a ragasztott száraztészta ridegen viselkedik, kevésbé türi a hajlítást.

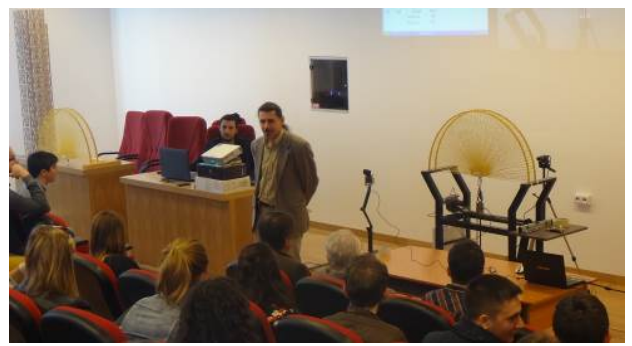

5. ábra. Kép a helyi selejtezöröl, a használt berendezésekkel (töröállvány és mérömüszerek)

A gyakorlati töréspróbákra a fenti megfontolásokból elmozdulásmérő rendszert is alkalmaztunk (egy $75 \mathrm{~mm}$-es Pentax lencséjü, 2448×2048-as felbontású, másodpercenként 75 keretet rögzítő Sony IMX250-es kamerával, amit egy VIC-2D digitális képkorrelációs mérőrendszerhez csatlakoztattunk), mint az 5. és 6. ábra szemlélteti.

A két csapat azonos geometriájú (a 2. ábrán látható) szerkezetekkel jelentkezett, így a teherbírásbeli különbség csupán a kivitelezési pontatlanságokból adódhatott.
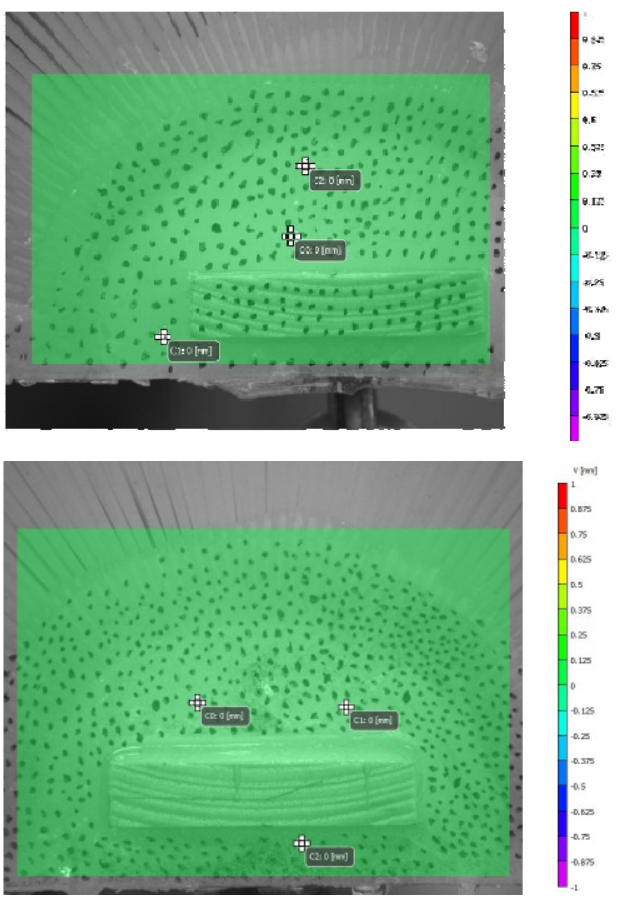

6. ábra. A digitális képkorrelációs rendszerhez szükséges pontok kijelölése (az elmozdulások kiszámitásához) a két híd terhelöeleménél

Az elmozdulásmérő rendszer alkalmazása nagyon szerencsésnek bizonyult, mert - bár a törőállványunk húzórendszere 800 kg-erö feletti terhelésre volt kivitelezve 410 kg-erőnél lefagyott a húzórendszer, mindkét alkalommal. Így az esetleges balesetek elkerülése végett várnunk kellett, amíg a tésztahidak szétroppantak.

A végső teherbírást utólag, mindkét esetben, $440 \mathrm{~kg}$-erő körüli értékre becsültük az elmozdulásmérő berendezés által rögzített adatok kiértékelése alapján.

\section{Megmérettetés a RECCS-en}

A RECCS 2016-ra e két csapattal jelentkeztünk. A „Musztáng” ugyanolyan geometriájú szerkezettel indult, mint ami- 
lyent a helyi vetélkedőre épített, míg a „Kamikaze” egy áttervezett geometriájú tésztahíddal (7. ábra) próbálkozott.

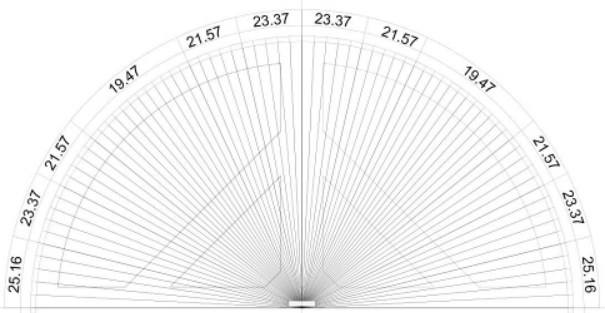

7. ábra. A „Kamikaze” csapat által használt új sablon, váltakozó küllökiosztással

5. táblázat. $A z$ újabb híd számítási eredményei, soronként a feltüntetett terhelésre. A kihasználtság itt is \%-ban értendö

\begin{tabular}{|c|c|c|c|c|}
\hline \multirow{2}{*}{$\begin{array}{c}\text { Bekötők } \\
{[d a N]}\end{array}$} & \multirow{2}{*}{$\begin{array}{l}\text { Ívek } \\
{[k N]}\end{array}$} & \multirow{2}{*}{$\begin{array}{c}\text { Süllyedés } \\
{[\mathrm{mm}]}\end{array}$} & \multicolumn{2}{|c|}{ Kihasználtság } \\
\hline & & & Bekötők & Ívek \\
\hline \multicolumn{5}{|c|}{ Terhelés [kg-eró]: $\quad 450$} \\
\hline 5,34 & $-1,11$ & 8,99 & 59,3 & 64,7 \\
\hline \multicolumn{5}{|c|}{ Terhelés [kg-erö]: $\quad 500$} \\
\hline 5,93 & $-1,23$ & 9,98 & 65,9 & 68,3 \\
\hline \multicolumn{5}{|c|}{ Terhelés [kg-eró]: $\quad 550$} \\
\hline 6,52 & $-1,35$ & 10,98 & 72,4 & 75,0 \\
\hline \multicolumn{5}{|c|}{ Terhelés [kg-eró]: $\quad 600$} \\
\hline 7,12 & $-1,47$ & 11,98 & 79,1 & 81,7 \\
\hline
\end{tabular}

A 4. és 5. táblázat értékeiből észlelhető, hogy a változatos küllőkiosztás nem okoz számottevő eltérést a bekötők meg az ívek igénybevételében (bár az új híd esetében a bekötők meg az ívek kihasználtság hányada közelebb került egymáshoz). Az ívekben szinte azonos nyomás keletkezik, olyannyira, hogy $K N$-ban kifejezve azonosak az értékek, de a terhelési pont úthossza az újabb modellnél csökkent (mind az 5 erö értékére).

Mindkét hidat Budapesten, az Óbudai Egyetem által rendelkezésre bocsátott munkahelyiségben építették meg a csapatok 5 nap leforgása alatt.

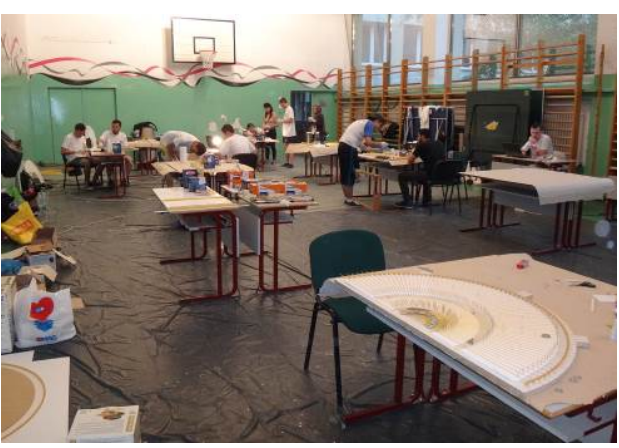

8. ábra. Tésztahidak épitése a munkahelyiségben

A 2016-os világbajnokságon hét ország (Bulgária, Irán, Lettország, Litvánia, Magyarország, Románia és Törökország) felsőoktatási intézményeiből érkezett csapatok vettek részt. A szervezők az előzetes elbírálás után 6 híd és 10 tartó nevezését fogadták el.

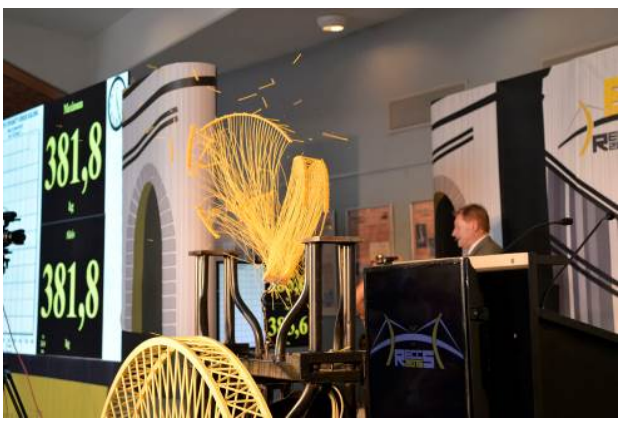

9. ábra. Verseny közben szétrobbanó tartó [1]

A legjobb eredményt a lettországi Rigai Müszaki Egyetem „Stiks 7” csapata (Lubgans Lauris, Lodītis Lauris és Zeps Kristaps) érte el 468,8 kg-erövel a tartó kategóriában. A harmadik helyet is ök szerezték meg, míg a második helyen az Óbudai Egyetem csapata végzett [1].

A híd kategóriában a kolozsvári „Kamikaze” csapat (Zajzon Csaba, Szász Gábor, Ambrus Lénárd és Bálint Róbert) lett a nyertes 455,3 kg-erō végső teherbírással, második helyen a törökországi Atatürk Egyetem csapata végzett, míg a szintén kolozsvári „Musztáng” csapat (Veres Le- 
vente, Balázs Levente, Takács Edmond és Kiss Tekla) 430,9 kg-erővel érdemelte ki a harmadik helyet [1].

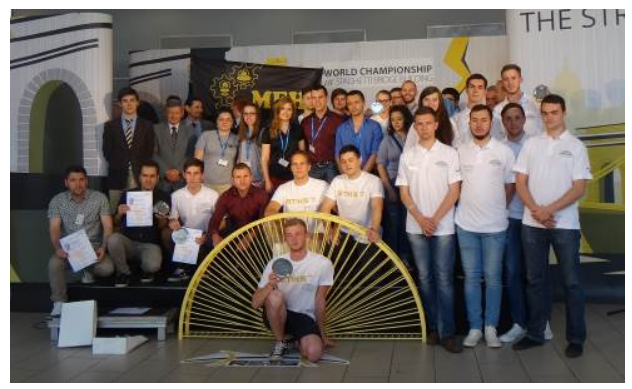

10. ábra. Csoportkép a RECCS 2016 dijazott csapataival (fehér trikóban középen a rigai ,, Stiks 7" csapat, jobboldalt pedig a kolozsvári „Musztáng” és „Kamikaze” csapat látható).

\section{Következtetések}

A RECCS honlaprendszerén [1] közzétett adatok szerint a nyertes „Kamikaze” csapat hídjánál a terhelési pont gyakorlatilag 9-10 mm-nyi utat tett meg a vonólánc megfeszülésétől a tésztahíd szétroppanásáig, míg a „Musztáng” csapat hídjánál ez valamivel kevesebb, 8-9 $\mathrm{mm}$ körüli érték volt. Kolozsvárra visszatérve újravizsgáltuk a két szerkezet modelljét, hogy értékelni tudjuk a kivitelezések pontosságát és a megépített tésztahidak viselkedését a RECCS-en elért eredmények tükrében.

A „Kamikaze” csapat hídja 455,3 kg-erö terhelésre 9,09 $\mathrm{mm}$ lehajlást eredményezett (a maximális erök értéke 1119,7 $N$ nyomás volt az ívekben és 54,04 $N$ húzás a bekötőkben). A „Musztáng” csapat hídja 403,9 kg-erő terhelésre $8,69 \mathrm{~mm}$ lehajlást eredményezett (a maximális erök értéke 1059,6 N nyomás volt az ívekben és 47,92 $N$ húzás a bekötőkben). Ezek az értékek igazolták, hogy a szerkezeti modellek statikai vizsgálatánál a lineáris rugalmas számítás megfelel, nem érdemes másodfokú geometriai vagy fizikai modellekkel komplikálódni. Másrészt azt is igazolták (amit egyébként a szerkezetek építésekor is tapasztaltam és kifogásoltam), hogy a hallgatóink nem ügyeltek kellőképpen a kivitelezés pontosságára, ugyanis az íveket alkotó részek a „Kamikaze” csapat esetében 65\% körüli kihasználtságnál, a „Musztáng” csapat esetében pedig $60 \%$ alatti kihasználtságnál roppantak szét.

A RECCS 2016-on tapasztalt és mért értékek, majd az itthon újraszámított szerkezeti modellek vizsgálata azt is alátámasztotta, hogy a tésztahidak tervezésénél érdemesebb az alakváltozásra figyelni, mint az alkotóelemek végfeszültségeire. A szerkezeti geometria függvényében változik a terhelési pont útjának a hossza, ezért érdemes olyan alaki változatokat keresni, amelyeknél ugyanakkora teherre minimális lesz ez az elmozdulás.

A legfontosabb dolog talán nem is a számítási eljárás vagy az elért eredmény, hanem az, hogy különböző országok felsőfokú intézményeinek a hallgatói megismerhetik egymást, összemérhetik az alkalmazott tudásuk szintjét, ügyességüket, és önbizalmat meg nemzetközi elismerést nyernek hála az Óbudai Egyetem által szervezett világbajnokságnak.

\section{Szakirodalmi hivatkozások}

[1] RECCS 2017 - Tésztahíd építő világbajnokság, http://reccs.uni-obuda.hu/hu/ (hozzáférés ideje: 2016.11.03), Óbudai Egyetem, Budapest, Magyarország.

[2]A wikipédia szerzői: Spaghetti bridge, https: //en.wikipedia.org/wiki/Spaghetti_bridge (hozzáférés ideje: 2016.11.03).

[3] Bíró Cs., Hadi Sz., Kádár Gy., Kis A., Péntek M.: Szerkezet-modellezés száraztésztából. 13. E-MTDK (Temesvár, 2011. április 810.), Orizonturi Universitare kiadó, Temesvár, Románia, 2011.

[4]Bartalis Sz., Bárdi Z., Geréb A.: Száraztésztából épült híd modellezése. 16. E-MTDK (Temesvár, 2015. május 15-17.), U.P.T., Temesvár, Románia, 2015. 